\title{
Correspondence
}

\section{Cytotaxonomic considerations on the sex chromosome variation observed within Acomys ngurui Verheyen et al. 2011 (Rodentia Muridae)}

\author{
RICCARDO CASTIGLIA ${ }^{1,2}$ \& FLAVIA ANNESI ${ }^{1}$ \\ 'Dipartimento di Biologia e Biotecnologie “Charles Darwin”, Università di Roma "La Sapienza”, via A. Borelli 50, 00161 Roma, \\ Italy.E-mail: castiglia@uniromal.it \\ ${ }^{2}$ Corresponding author
}

The taxonomy of the East African Muridae belonging to the Acomys spinosissimus Peters 1852 species complex has been recently revised (Verheyen et al., 2011). Two new species have been described by means of external morphologic analysis, craniometry, enzymes, mitochondrial DNA sequences and karyological information. For one of the two new species, Acomys ngurui Verheyen et al. 2011, a polymorphic karyotype has been observed. In fact, for 19 of the 22 karyotyped individuals, the karyotype is identical to the one described for A. spinosissimus s. $\mathrm{s} .(2 \mathrm{n}=60, \mathrm{aFN}=68)$, characterized by a sex chromosome constitution of the XX/XY type, with an acrocentric X and a submetacentric $\mathrm{Y}$ (Dippenaar and Rautenbach, 1986). The remaining three females possess a karyotype that resembles the one reported by Matthey (1965) and Barome et al. (2001) characterized by a unique giant metacentric X chromosome $\left(\mathrm{X}_{\mathrm{g}}\right)$, and by a variable diploid number $(2 \mathrm{n}=59-62)$. These females were found in the three localities in Tanzania together with specimens with the typical 'spinosissimus' karyotype. Specimens carrying the $\mathrm{X}_{\mathrm{g}}$ were not distinguishable on the basis of their mtDNA sequence or morphology from the other specimens with XY karyotype (Verheyen et al., 2011). The authors concluded that the available evidence did not allow one to give taxonomic value to this chromosomal configuration, characterized by a particular sex determination, hoping for future work that will study the animals bearing this typical karyotype in more detail.

Actually, these cytogenetic studies are already available for this odd karyotype. In fact five specimens (two males and three females) have been recently studied by mean of C-G banding pattern and male diakinesis (Castiglia et al. 2007). For this reason we are now able to taxonomically evaluate these cytogenetic observations thanks to the molecular and morphological data presented by Verheyen et al. (2011).

Instead of a particular new sex determination system, the cytogenetic analysis by Castiglia et al. (2007) revealed that males and females with the $\mathrm{X}_{\mathrm{g}}$ constitute mosaics for sex chromosomes (Fig. 1A). Females have an excess of aneuploid cells with one $\mathrm{X}_{\mathrm{g}}$ chromosome. Only in one out of three females' two cells with two $\mathrm{X}_{\mathrm{g}} \mathrm{s}$ were found in a total of thirtytwo observed cells. Males are mosaic with $\mathrm{X}_{\mathrm{g}} \mathrm{O}$ or $\mathrm{X}_{\mathrm{g}} \mathrm{Y}$ cells in somatic tissues, and only $\mathrm{X}_{\mathrm{g}} \mathrm{Y}$ cells in the germinal lineage. The female meiosis was not studied, but the occurrence of mosaicism for $X_{g}$ chromosomes $\left(X_{g} X_{g} / X_{g} O\right)$ in one female supports the hypothesis of a post-meiotic elimination of $\mathrm{X}_{\mathrm{g}}$ in this individual. In addition, an odd heterochromatic submetacentric chromosome was found in three out of five specimens. This chromosome resembles the $\mathrm{Y}$ chromosome of the "spinosissimus" karyotype, but it is not related to sex determination because it is present in both sexes. Moreover, since it is not present in all the analyzed specimens, it can be considered as a B chromosome (Castiglia et al. 2007).

Since only one specimen with the $X_{\mathrm{g}}$ was sequenced (Verheyen et al. 2011; Barome et al. 2011) we sequenced the cytochrome b gene (cytb) of three of the specimens studied by Castiglia et al. (2007) (1140 bp, GenBank accession numbers: JX244273-5). A minimum spanning network was build with Network 4.6 including the $c y t b$ sequences of all the so far karyotyped specimens belonging to Acomys ngurui (Fig. 1B, Table 1). Since the two karyotypes, namely those containing and those not containing $\mathrm{X}_{\mathrm{g}}$ chromosomes, occur also in syntopy, sequences of specimens for which no karyotypes are available are excluded from the analysis. Two groups of haplotypes are evident, corresponding to the geographically separated "MOTU11" and "MOTU20" showed in the tree in Fig. 4 of Verheyen et al. (2011). The mean genetic divergence between the two groups is $1.8 \%$ (p-distance), a value often reported as within the limits of intraspecific variation in mammals (Baker and Bradley 2006). MOTU20 includes only specimens with the "spinosissimus" karyotype, while in MOTU11, the haplotype (h7) is shared by two specimens with different karyotypes (Fig. 1B). These data confirm the coexistence of these two cytotypes without a detectable mtDNA variation. Thus, the 
taxonomic status of the two cytotypes can be evaluated only considering the observed chromosomal differences that do not seem to be sufficiently important to represent a reproductive barrier. In fact, the comparison of the G-banding for the constant autosomal part of the two karyotypes reveals that these are identical (Castiglia et al. 2007). Eventual hybrid females' would be expected to carry one acrocentric $\mathrm{X}$ and one $\mathrm{X}_{\mathrm{g}}$ whose the only difference would consist in a long heterochromatic arm. This type of chromosomal variation has been repeatedly found as floating polymorphism in many African Murinae (e.g., Dasymys Volobouev et al. 2000; Arvicanthis: Garagna et al. 2001; Lemniscomys: Castiglia et al. 2002).

TABLE 1. Localities, sex Chromosome constitution (see Fig. 1A for details) and haplotype designation in Acomys ngurui specimens from Tanzania (RMCA: Royal Museum for Central Africa, Tervuren, Belgium; MNHN Muséum National d'Histoire Naturelle, Paris, France; ROMA: Museo di Anatomia Comparata G.B. Grassi, Rome, Italy).

\begin{tabular}{|c|c|c|c|c|c|}
\hline voucher & $\begin{array}{l}\text { Locality } \\
\text { (coordinates) }\end{array}$ & Karyotype & haplotype & GenBank & source \\
\hline RMCA 96.037.M.4990 & $\begin{array}{l}\text { Chingulungulu } \\
(10.44 \mathrm{~S}-38.33 \mathrm{E})\end{array}$ & XY & H1 & JN247724 & Verheyen et al. (2011) \\
\hline RMCA 96.037.M.4974 & $\begin{array}{l}\text { Mnara } \\
(10.07 \mathrm{~S}-39.24 \mathrm{E})\end{array}$ & XY & $\mathrm{H} 2$ & JN247690 & Verheyen et al. (2011) \\
\hline RMCA 96.037.M.5004 & $\begin{array}{l}\text { Nakahuga } \\
(10.39 \mathrm{~S}-35.27 \mathrm{E})\end{array}$ & XY & H3 & JN247728 & Verheyen et al. (2011) \\
\hline RMCA 96.037.M.4981 & $\begin{array}{l}\text { Mnima } \\
(10.37 \mathrm{~S}-39.13 \mathrm{E})\end{array}$ & $X Y$ & $\mathrm{H} 4$ & JN247722 & Verheyen et al. (2011) \\
\hline ROMA TZ511 & $\begin{array}{l}\text { Berega } \\
(06.09 \mathrm{~S}-37.14 \mathrm{E})\end{array}$ & $\mathrm{X}_{\mathrm{g}} \mathrm{O}+\mathrm{B}$ & H5 & JX244273 & $\begin{array}{l}\text { Castiglia et al. (2007), } \\
\text { present data }\end{array}$ \\
\hline ROMA TZ521 & $\begin{array}{l}\text { Berega } \\
(06.09 \mathrm{~S}-37.14 \mathrm{E})\end{array}$ & $\mathrm{X}_{\mathrm{g}} \mathrm{O} / \mathrm{X}_{\mathrm{g}} \mathrm{X}_{\mathrm{g}}$ mosaic & H6 & JX244274 & $\begin{array}{l}\text { Castiglia et al. (2007), } \\
\text { present data }\end{array}$ \\
\hline RMCA 96.037.M.5011 & $\begin{array}{l}\text { Mkundi } \\
(06.42 \mathrm{~S}-37.39 \mathrm{E})\end{array}$ & $\mathrm{XX}$ & $\mathrm{H} 7$ & JN247717 & Verheyen et al. (2011) \\
\hline ROMA T50544 & $\begin{array}{l}\text { Dakawa } \\
(06.26 \mathrm{~S}-37.34 \mathrm{E})\end{array}$ & $\mathrm{X}_{\mathrm{g}} \mathrm{O}$ & $\mathrm{H} 7$ & JX244275 & $\begin{array}{l}\text { Castiglia et al. (2007), } \\
\text { present data }\end{array}$ \\
\hline MNHN-CG 1998- 1611 & $\begin{array}{l}\text { Berega } \\
(06.09 \mathrm{~S}-37.14 \mathrm{E})\end{array}$ & $\mathrm{X}_{\mathrm{g}} \mathrm{O} / \mathrm{X}_{\mathrm{g}} \mathrm{Y}+\mathrm{B}$ mosaic & $\mathrm{H} 8$ & AJ010599 & Barome et al. (2001) \\
\hline
\end{tabular}

There is no evidence for reduced fertility between cytotypes possessing structural heterozygosity for the amount and/or location of heterochromatin (reviewed in Romanenko and Volobouev 2012). However, in a few cases a deleterious effect of heterochromatin in heterozygous condition has been suggested as in hybrids between karyotypes belonging to the Mus terricolor complex (Sharma et al. 2003) or in Nesokia indica (Thelma et al. 1988). The latter species shows a peculiar condition where some infrequent variants of the $\mathrm{X}$ and the $\mathrm{Y}$ chromosomes, with deletions in the heterochromatic arm, provoke complete sterility in the carriers. However, the high deleterious effect on the carriers should prevent any spreading and fixation of these chromosomal rearrangements and their role in speciation is questionable.

Unfortunately, the unambiguous identification of hybrid karyotypes is almost impossible in Acomys ngurui if differential staining techniques (G-C banding) are not applied. In fact, the acrocentric $\mathrm{X}$ chromosome of the "spinosissimus" karyotype and both the Y chromosomes are virtually indistinguishable from autosomes. The situation is further complicated by the presence of an odd B chromosome, easily identifiable only with C-banding, that is very similar to the Y chromosome of the "spinosissimus" karyotype (Fig. 1). We cannot exclude that the karyotype of the male individual (RMCA 96.036.M.438), indicated in Table 4 by Verheyen et al. (2011) as a male with $2 \mathrm{n}=60$ and an acrocentric $\mathrm{X}$ and unidentified Y (reported as "X?"), is a hybrid between the two cytotypes.

Relying on the available data, the sex chromosomal variation observed within A. ngurui represents an interesting instance of intraspecific variation that involves the existence of both mosaic and normal individuals with sex chromosome polymorphism. To the best of our knowledge, this particular situation has not been observed in any other mammal before, also because mosaics for sex chromosomes are extremely rare: so far they have only been noticed to occur frequently in four genera of the bandicoot family Peramelidae (Hayman and Martin 1974). The possible role of such a mosaicism in the evolutionary appearance of new sex chromosome system, as observed in other species (e.g. Nannomys, Veyrunes et al. 2010; Ellobius, Vogel et al. 1998) requires additional studies. 


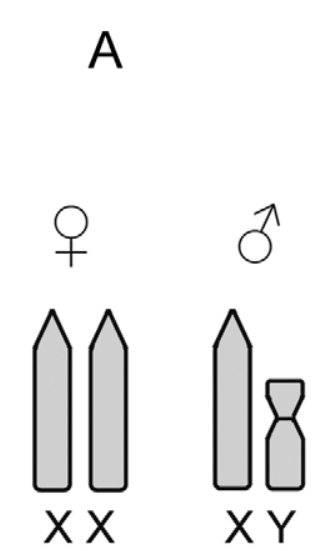

Normal "spinosissimus"
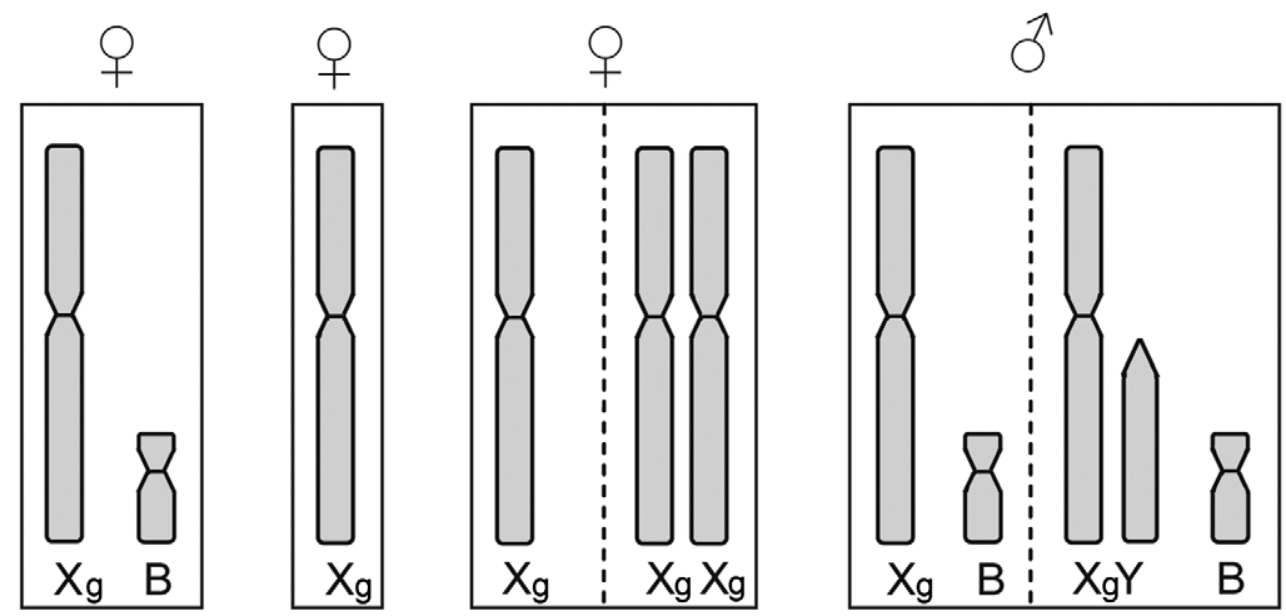

$$
\mathrm{XgO}+\mathrm{B}
$$

\section{$\mathrm{XgO}_{\mathrm{g}} \mathrm{Xg}_{\mathrm{g}} \mathrm{X}_{\mathrm{g}}$ mosaic}

$\mathrm{XgO} / \mathrm{XgY}$ mosaic $+\mathrm{B}$

B

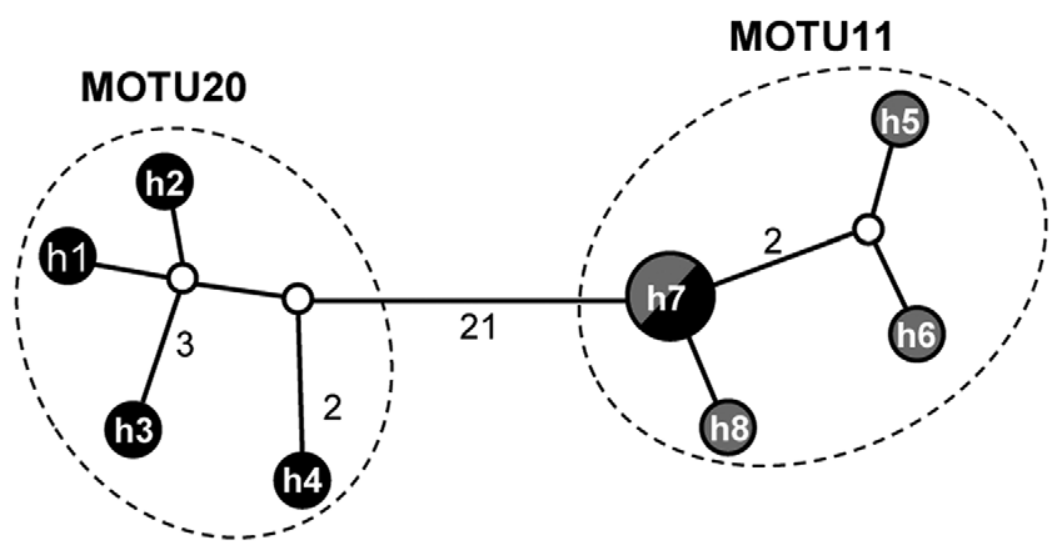

FIGURE 1. A, schematic representation of sex chromosomes variation in Acomys ngurui following Castiglia et al. (2007). Only the variable part of the karyotypes are presented. Normal "spinosissimus" karyotype has XY-XX sex chromosomes. Other karyotypes show a giant $\mathrm{X}_{\mathrm{g}}$ mosaicism for sex chromosomes and a submetacentric B chromosome. B, median-joining network of cytb haplotypes (1140 bp). Black and grey circles indicate specimens with normal "spinosissimus" karyotype and specimens carrying $\mathrm{X}_{\mathrm{g}}$, respectively. White circles indicate missing haplotypes. The two groups of haplotypes separated by 21 substitutions correspond to "MOTU11" and "MOTU20" in the tree in Fig. 4 of Verheyen et al. (2011).

\section{Acknowledgments}

We thank Erik Verheyen and an anonymous reviewer for their helpful comment on the manuscript. RC received financial support by "Progetti di ricerca Università di Roma La Sapienza".

\section{References}

Baker, R.J. \& Bradley, R.D. (2006) Speciation in mammals and the genetic species concept. Journal of Mammalogy, 87, 643-662.

Barome, P.O., Volobouev, V., Monnerot, M., Mfune, J.K., Chitaukali, W., Gautun, J.-C. \& Denys, C. (2001) Phylogeny of Acomys spinosissimus (Rodentia, Muridae) from north Malawi and Tanzania: evidence from morphological and molecular analysis. Biological Journal of the Linnean Society, 73, 321-340.

Castiglia, R., Fadda, C., Corti, M., Scanzani, A., Verheyen, W. \& Capanna E. (2002) Chromosomal evolution in the African Arvicanthine rats (Murinae, Rodentia): comparative cytogenetics of Lemniscomys (L. zebra, L. rosalia, L. striatus) and Arvicanthis dembeensis. Journal of Zoological Systematics and Evolutionary Research, 40, $223-231$. 
Castiglia, R., Makundi, R. \& Corti, M. (2007) The origin of an unusual sex chromosome constitution in Acomys sp. (Rodentia, Muridae) from Tanzania. Genetica, 131, 201-207.

Dippenaar, N.J.J. \& Rautenbach, I.L. (1986) Morphometrics and karyology of the southern African species of the genus Acomys I. Geoffroy Saint-Hilaire, 1838 (Rodentia: Muridae). Annals of the Transvaal Museum, 34, 129-183.

Garagna, S., Civitelli, M.V., Marziliano, N., Castiglia, R., Zuccotti, M., Redi, C.A. \& Capanna, E. (1999) Genome size are related to X-chromosome heterochromatin polymorphism in Arvicanthis sp. from Benin. Italian Journal of Zoology, 66, 27-32.

Hayman, D.L. \& Martin, P.G. (1974) Mammalia 1: Monotremata and Marsupialia. In: John, B. (ed.), Animal cytogenetics 4. Chordata. Gebrü der Borntraeger, Berlin, $110 \mathrm{pp}$.

Matthey, R. (1965) Le probleme de la determination du sexe chez Acomys selousi de Winton-Cytogenetique du genre Acomys (Rodentia-Muridae). Revue Suisse de Zoologie, 72, 119-144.

Romanenko, S.A. \& Volobouev, V. (2012) Non-Sciuromorph Rodent Karyotypes in Evolution. Cytogenetic and Genome Research, 137, 233-245.

Sharma, T., Bardhan, A. \& Bahadyr, M. (2003) Reduced meiotic fitness in hybrids with heterozygosity for heterochromatin in the speciating Mus terricolor complex. Journal of Bioscience, 28, 189-198.

Thelma, B.K., Juyal, R.C., Tewari, R., Rao, S.R.V. (1988) Does heterochromatin variation potentiate speciation? Cytogenetics and Genome Research, 47, 204-208.

Verheyen, W., Hulselmans, J., Wendelen, W., Leirs, H., Corti, M., Backeljau, T. \& Verheyen, E. (2011) Contribution to the systematics and zoogeography of the East-African Acomys spinosissimus Peters 1852 species complex and the description of two new species (Rodentia: Muridae). Zootaxa, 3059, 1-35.

Veyrunes, F., Chevret, P., Catalan, J., Castiglia, R., Watson, J., Dobigny, G., Robinson, T.J., Britton-Davidian, J. (2010) A novel sex determination system in a close relative of the house mouse. Proceedings of the Royal Society B: Biological Sciences, 277, 1049-1056.

Vogel, W., Jainta, W., Rau, W., Geerkens, C., Baumstark, A., Correa-Cerro, L.S., Ebenhoch, C. \& Just W. (1998) Sex determination in Ellobius lutescens: the story of an enigma.Cytogenetic and Genome Research, 80, $214-221$.

Volobouev, V., Sicard, B., Aniskin, V.M., Gautun, J.C. \& Granjon, L. (2000) Robertsonian polymorphism, B chromosomes variation and sex chromosomes heteromorphism in the African water rat Dasymys (Rodentia, Muridae). Chromosome Research, 8, 689-697. 